\title{
The Effects of Salicylic Acid on The Growth and Some Physiological Properties of Bread Wheat Varieties Under Drought Stress
}

\author{
Yusuf ÖZTÜRKC $\dot{I}^{1 *}$, Diğdem ARPALI ${ }^{2}$
}

\begin{abstract}
This research was conducted at Department of Field Crops in Faculty of Agriculture in Yüzüncü Y1l University in 2014 , in the growth chamber under controlled conditions in terms of temperature and light, for 5 bread wheat varities (Doğu-88, Altay-2000, Bezostaja1, Alparslan and Tir mixed population line), for two different irrigation levels (using $40 \%$ of the field capacity for drought and $60 \%$ for control), through the application of two different salicylic acid dosage $\left(0.1 \mathrm{mM} \mathrm{kg}^{-1} \mathrm{SA}\right.$ and $1.0 \mathrm{mM} \mathrm{kg}^{-1} \mathrm{SA}$ ), with four repetitions in 80 pots with $4 \mathrm{~kg}$ soil capacity, with respect to randomized experimental design principles. In terms of the investigated characteristics, salicylic acid applications were found to be effective for the Bezostaja1, Doğu-88, Altay-2000 varieties and Tir wheat population line by enhancing their tolerance to drought and exhibited differences with respect to the salicylic acid doses $\left(0.1 \mathrm{mM} \mathrm{kg}^{-1}\right.$ and $\left.1.0 \mathrm{mM} \mathrm{kg}^{-1}\right)$. The characteristics, which were adversely affected when compared to the control application under drought conditions, were commonly positively affected by the salicylic acid applications.
\end{abstract}

Keywords: Bread wheat, drought, salicylic acid, physiological properties, growth,

\footnotetext{
${ }^{1}$ Yusuf ÖZTÜRKCİ (Orcid ID: 0000-0002-9122-5007), Agriculture and Rural Development Support Institution Van Province Coordination Unit, Van- Turkey

2 Diğdem ARPALI (Orcid ID: 0000-0003-1795-468X), University of Yuzuncu Yil, Faculty of Agriculture, Department of Field Crops, Van-Turkey

*Sorumlu Yazar / Corresponding Author: Yusuf ÖZTÜRKCİ, e-mail: ozturkciyusuf@gmail.com

Bu çalışma Yusuf ÖZTÜRKCI'nin doktora tezinin bir bölümüdür. Makale 11 Mayıs 2018 tarihinde Van'da düzenlenen International Agricultural Science Congress(9-12 Mayıs 2018 Uluslararası Tarım Bilimleri Kongresi) Kongresinde poster olarak sunulmuştur.
} 


\section{INTRODUCTION}

According to FAO data, wheat, which has a vital importance for humanity in terms of its ability to adapt, area of utilization, its prominence and precedence, is the second ranking crop type in the world with a production of 700 million tons, after corn that has 900 million tons of production (Anonymous, 2016a). In Turkey, wheat, which is planted in $67 \%$ of total crop fields and has about 20 million tons of production, ranks first (Anonymous, 2016b). Currently, country populations are in an increase, despite the decline of agricultural land due to various causes. Crops, which are among the most vital products in human and animal nutrition, should be at a sufficient level for the population. In such case, the necessity to develop different solutions in order to meet the human and animal nutrition emerges, since there exists no chance to increase agricultural areas. The most important environmental factor that hinders or negatively affects the plant growth and development is drought (Monti, 1986).

There are various applications that aim to increase the strength against stress conditions such as drought, and in recent years, external salicylic acid application is among these, as a method applied against stress conditions. The aim of this study is to determine the effects of salicylic acid application on the some morphological and physiological characteristics under drought stress for Bezostaja1, Doğu-88, Altay 2000, Alparslan bread wheat varieties and Tir wheat population line, those which their adaptation in Van region was previously determined through scientific research (Kaydan and Yagmur, 2008), and to provide an insight for further studies to be conducted.

\section{MATERIALS AND METHODS}

In this study, Doğu-88, Alparslan, Bezostaja1 and Altay-2000 bread wheat varieties and Tir wheat population line, which is prevalently planted in around the Van Lake region, were used. This research was conducted in 2014, in the growth chamber of the Department of Field Crops in Faculty of Agriculture in Yuzuncu Y1l University, for 5 bread wheat varieties, for two different irrigation levels (using $40 \%$ of the field capacity for drought and $60 \%$ for control), through the application of two different salicylic acid dosage $\left(\mathrm{SA}_{1}: 0.1 \mathrm{mM} \mathrm{kg}^{-1} \mathrm{SA}\right.$ and $\mathrm{SA}_{2}: 1.0$ $\mathrm{mM} \mathrm{kg}{ }^{-1} \mathrm{SA}$ ), with respect to completely random parcel experimental design principles with four repetitions in 80 pots with $4 \mathrm{~kg}$ soil capacity. The seeds were kept in a humidified environment for 12 hours, then were incubated for 6 weeks at $+2{ }^{\circ} \mathrm{C} \quad \mathrm{C}$ to supply their vernalization needs (Ferreira et al., 1995). Pure nitrogen and phosphorus, with the quantity of $100 \mathrm{mg} \mathrm{N} \mathrm{kg}^{-1}$ (AS) and $100 \mathrm{mg} \mathrm{P} \mathrm{kg}{ }^{-1}$ (TSP), were applied to the pots one day before the seeding. Soil samples were dried before chemical analysis and were sieved through a $2 \mathrm{~mm}$ sieve. For the chemical analyzes of the samples, the methods identified by Kacar (1995) were used. Salicylic acid was dissolved in distilled water. The stock solution was prepared by adjusting the $\mathrm{pH}$ to 6.5 via $\mathrm{NaOH}$. In preparing the stock solution the methods used by El-Tayeb, (2005) and Mutlu et al. (2013) were utilized. Two different doses were prepared from the stock, as $0.1 \mathrm{mM} \mathrm{kg}^{-1} \mathrm{SA}$ ve $1.0 \mathrm{mM} \mathrm{kg}^{-1}$ $\mathrm{SA}$, and the seeds were treated with salicylic acid and were incubated in the dark, at $22^{\circ} \mathrm{C}$, for 12 hours. Later, 10 seeds were planted to $5 \mathrm{~cm}$ depth for each pot in the climate chamber. During the application, ambient temperature was kept between 21 and $23^{\circ} \mathrm{C}$. The amount of light used in photosynthesis was measured with a lux meter and the amount of room light was kept between 550 and $600 \mathrm{mMm}^{-2}$ s. During the study, the plants were exposed to 16 hours of light and 8 hours of dark environment (Tavakkolli et al., 2012). Neme Noor trademark bulbs, giving a white light of $50 \mathrm{~W}$ power that is equivalent to $250 \mathrm{~W}$, were used as the light sources in this study.The determining of leaf 
osmotic potential, extracts were prepared from leaves by using Jones and Turner (1978) method. The osmolality (-MPa) was determined by using a Vapour-pressure osmometer (Vapro Osmometer). Membrane permeability was determined according to the method of Premchandra et al. (1990) as modified by Sairam, 1994. Leaf discs (100 mg) were thoroughly washed in running tap water followed by washing with double distilled water thereafter the discs were heated in $10 \mathrm{ml}$ of double distilled water at $40{ }^{0} \mathrm{C}$ for $30 \mathrm{~min}$. Then electrical conductivity (C1) was recorded by EC (Electrical Conductivity) meter. Subsequently the same samples were placed in a boiling water bath $\left(100{ }^{0} \mathrm{C}\right)$ for $10 \mathrm{~min}$ and their electrical conductivity was also recorded $(\mathrm{C} 2)$. The MP was calculated as: $\left[1-\left(\mathrm{C} 1 \mathrm{C}^{-1}\right)\right] \times 100$. (Premchandra et al., 1990; Sairam, 1994), The amount of chlorophyll, was determined by per leaf sample using chlorophyll meter (SPAD-502, Minolta Corp.). Water-retention capacity of the leaf, the youngest fully expanded leaves were selected in each plot. The leaves were placed in plastic bags and transported to the laboratory as quickly as possible. Samples from each plot were taped together with the plot identification. Fresh weight was determined (W0) on an electronic balance. The leaves were then placed in a controlled environment room at $25{ }^{\circ} \mathrm{C}$ and $50 \%$ relative humidity for six hours. The leaves were removed and weighed at 2, 4, and 6 hours (W2, W4, and W6), and then placed in an oven at $50{ }^{\circ} \mathrm{C}$ for 24 hours and reweighed (Wd ). RWL was determined as: $\mathrm{RWL}=(\mathrm{W} 0-\mathrm{W} 2)+(\mathrm{W} 2-$ $\mathrm{W} 4)+(\mathrm{W} 4-\mathrm{W} 6) 3 \times \mathrm{Wd}(\mathrm{T} 2-\mathrm{T} 1)$ where $\mathrm{T} 1-$ $\mathrm{T} 2$ = time interval between two subsequent measurements $(2 \mathrm{~h})$. Fresh and dry weight above ground, fresh and dry Weight Underground, after harvest, the seedlings were separated into shoots and roots, and rinsed thoroughly with deionized water. The dry weight (DW) of shoots and roots were recorded after dried at $70{ }^{\circ} \mathrm{C}$ for 48 hours (Bray, 1963).
The data analysis was performed in SAS 9.2 (2008) and SPSS 20 softwares. In order to test the normal distribution of the data Shapiro-Wilk test and to conduct variance homogeneity test Levene test were performed. Multiple comparisons under the Kruskal-Wallis test, which is a non-parametric test, was conducted since the data did not meet the assumptions of normality and homogeneous variance.

\section{RESULTS AND DISCUSSION}

\section{Osmotic Potential}

The differences between the applications were found to be statistically significant for all varieties. Because of osmotic potential has negative values, the values that close to zero indicates high osmotic potential and far from zero indicates low values of osmotic potential(Table 1). The highest values for all varieties were identified in the control application, except the Bezostajal variety, the response of the varieties to salicylic acid applications were found to be different. While salicylic acid increased the osmotic potential in Tir and Altay 2000 varieties, it decreased the osmotic potential in Alparslan variety. For Doğu-88 variety, different results were obtained depending on the dosage of application, for Bezostaja1 variety, the highest value was obtained in drought application and the lowest value was obtained in control application, and the salicylic acid application were ranked within this range (Table 1). Khaliq et al. (1999) stated that the osmotic potentials of wheat varieties differ in drought conditions and this phenomenon is related to the flag leaf area, stoma size and epidermal cell size. Salicylic acid applications generally increased the osmotic potential under stress conditions. Kaydan et al. (2007) reported that salicylic acid applications provide strength for the plant against the stress conditions of water and salt and increase the osmotic potential of the plant. 
Table 1. The Effect of Salicylic Acid on the Osmotic Potential of the Wheat Varieties Cultivated under Drought Conditions

\begin{tabular}{llllll}
\hline \multicolumn{5}{c}{ Osmotic Potential (-MPa) (mean \pm standard deviation $(\mathrm{n}=4)$} \\
\hline \multirow{2}{*}{ Applications } & \multicolumn{5}{c}{ Varieties } \\
\cline { 2 - 6 } & Tir & Doğu- 88 & Alparslan & Altay 2000 & Bezostaja1 \\
\hline Control & $0.91 \pm 0.02^{\mathrm{a}}$ & $0.88 \pm 0.00^{\mathrm{a}}$ & $0.92 \pm 0.00^{\mathrm{a}}$ & $0.92 \pm 0.00^{\mathrm{a}}$ & $1.04 \pm 0.00^{\mathrm{b}}$ \\
Drought & $1.14 \pm 0.01^{\mathrm{b}}$ & $0.98 \pm 0.02^{\mathrm{bc}}$ & $0.99 \pm 0.00^{\mathrm{ab}}$ & $1.05 \pm 0.00^{\mathrm{b}}$ & $0.94 \pm 0.00^{\mathrm{a}}$ \\
Drought+SA1 & $0.94 \pm 0.00^{\mathrm{ab}}$ & $0.99 \pm 0.00^{\mathrm{c}}$ & $1.12 \pm 0.00^{\mathrm{ab}}$ & $0.93 \pm 0.00^{\mathrm{ab}}$ & $1.01 \pm 0.00^{\mathrm{ab}}$ \\
Drought+SA2 & $0.98 \pm 0.00^{\mathrm{ab}}$ & $0.95 \pm 0.00^{\mathrm{ab}}$ & $1.30 \pm 0.00^{\mathrm{b}}$ & $0.94 \pm 0.00^{\mathrm{ab}}$ & $0.97 \pm 0.00^{\mathrm{ab}}$ \\
$\mathrm{P}$ value & $\mathrm{P}<0.01$ & $\mathrm{P}<0.01$ & $\mathrm{P}<0.01$ & $\mathrm{P}<0.01$ & $\mathrm{P}<0.01$ \\
\hline
\end{tabular}

$\mathrm{P}<0.01$, different letters indicate means significantly different

\section{Membrane Permeability}

Membrane permeability, which is utilized in determining the damage occurred in the membranes due to the decrease of the amount of water in the cells, increased with the application of drought and only for Tir wheat, it was not found to be statistically significant. For the varieties except Doğu-88, membrane permeability increased in accordance with the application dose of salicylic acid (Table 2). Membrane permeability, which is one of the criteria in determination of tolerance towards drought and salinity Blum and Ebrecon (1981), is expressed as an ion imbalance due to intracellular and extracellular osmotic incompatibility in plants under stress conditions (Bajji et al., 2002). The increase in membrane permeability in drought condition was reported in several studies by Munns et al. (2002) for wheat, by (Coban, 2007) for chickpea, by PerezLopez et al. (2008) for barley, and by Kusvuran (2010) for melon. The outcomes of these research support the results achieved through the drought application. Nemeth et al. (2002) stated that salicylic acid application in corn under drought stress adversely affected photosynthesis activity due to reduced stomatal density and transpiration, and increased the membrane damage significantly.

Table 2. The Effect of Salicylic Acid on the Membrane Permeability of the Wheat Varieties Cultivated under Drought Conditions

\begin{tabular}{llllcc}
\hline \multicolumn{5}{c}{ Membrane Permeability (\%) (mean \pm standard deviation $(\mathrm{n}=4)$} \\
\hline \multirow{2}{*}{ Applications } & \multicolumn{5}{c}{ Varieties } \\
\cline { 2 - 6 } & Tir & Doğu-88 & Alparslan & Altay 2000 & Bezostaja1 \\
\hline Control & $11.73 \pm 1.50$ & $10.21 \pm 1.48^{\mathrm{b}}$ & $7.89 \pm 1.96^{\mathrm{b}}$ & $7.87 \pm 0.89^{\mathrm{b}}$ & $8.16 \pm 0.97^{\mathrm{b}}$ \\
Drought & $18.72 \pm 8.62$ & $11.71 \pm 2.47^{\mathrm{ab}}$ & $10.60 \pm 3.65^{\mathrm{ab}}$ & $15.50 \pm 2.08^{\mathrm{ab}}$ & $11.27 \pm 1.42^{\mathrm{ab}}$ \\
Drought+SA1 & $14.58 \pm 4.95$ & $20.02 \pm 3.89^{\mathrm{a}}$ & $10.49 \pm 2.00^{\mathrm{ab}}$ & $13.60 \pm 5.10^{\mathrm{ab}}$ & $18.35 \pm 0.52^{\mathrm{ab}}$ \\
Drought+SA2 & $20.15 \pm 4.79$ & $18.12 \pm 4.22^{\mathrm{ab}}$ & $18.60 \pm 3.88^{\mathrm{a}}$ & $21.36 \pm 2.65^{\mathrm{a}}$ & $23.48 \pm 4.25^{\mathrm{a}}$ \\
P value & $\mathrm{ns}$ & $\mathrm{P}<0.05$ & $\mathrm{P}<0.05$ & $\mathrm{P}<0.01$ & $\mathrm{P}<0.01$ \\
\hline
\end{tabular}

$\mathrm{p}<0.01, \mathrm{P}<0.05$ different letters indicate means significantly different, ns: not significant

\section{The Amount of Chlorophyll}

The differences between the applications were determined as statistically significant for the Doğu-88 and Altay 2000 varieties. The amount of chlorophyll increased in the Doğu- 88 variety due to drought, and decreased in the Altay 2000 variety. Salicylic acid application increased the amount of chlorophyll in both varieties (Table 3). The findings of Kabiri et al., (2014), regarding that the increase in the chlorophyll content due to salicylic acid application under drought conditions could originate from the decrease of pigments that degraded as a result of water deficiency rather than the synthesis of chlorophyll and that the application of salicylic acid provided strength for the plant against the negative effect of the water stress, support the outcomes of this study. According to the results obtained in this study, a decrease in the amount of chlorophyll due to the 
drought stress could be explained through the phenomenon that the application of salicylic acid increases the content of chlorophyll via tolerating the adverse effect of the stress occurring in the plant and facilitates the plant to gain strength against this stress. In addition, several researchers reported that drought stress had no effect on the amount of chlorophyll (Kulshreshta et al., 1987) that onion plant increased its amount of chlorophyll under drought conditions (Beeflink et al., 1985) and with sesame the amount of chlorophyll remained stable after certain increase (Mensah et al., 2006). The different results that researchers obtained could be explained by the severity of the applied drought conditions, the duration of the application and different study conditions (Jagtap et al., 1998).

Table 3. The Effect of Salicylic Acid on the Amount of Chlorophyll of the Wheat Varieties Cultivated under Drought Conditions

\begin{tabular}{lllllc}
\hline \multicolumn{5}{c}{ Amount of Chlorophyll $(\mu \mathrm{g} / \mathrm{mg})($ mean \pm standard deviation $\mathrm{n}=4)$} \\
\hline \multirow{2}{*}{ Applications } & \multicolumn{5}{c}{ Varieties } \\
\cline { 2 - 6 } & Tir & Doğu-88 & Alparslan & Altay 2000 & Bezostaja1 \\
\hline Control & $54.30 \pm 5.06$ & $47.95 \pm 3.51^{\mathrm{b}}$ & $48.05 \pm 3.30$ & $60.15 \pm 3.69^{\mathrm{a}}$ & $54.30 \pm 6.34$ \\
Drought & $49.50 \pm 0.69$ & $50.90 \pm 0.69^{\mathrm{ab}}$ & $50.00 \pm 4.50$ & $51.83 \pm 2.16^{\mathrm{b}}$ & $52.00 \pm 0.12$ \\
Drought+SA1 & $56.80 \pm 1.50$ & $49.92 \pm 0.79^{\mathrm{ab}}$ & $47.12 \pm 0.83$ & $56.20 \pm 1.62^{\mathrm{ab}}$ & $51.40 \pm 2.73$ \\
Drought+SA2 & $55.37 \pm 3.15$ & $57.26 \pm 3.25^{\mathrm{a}}$ & $47.04 \pm 4.44$ & $57.29 \pm 2.66^{\mathrm{ab}}$ & $57.33 \pm 2.94$ \\
\multicolumn{1}{c}{ P value } & $\mathrm{ns}$ & $\mathrm{P}<0.05$ & $\mathrm{~ns}$ & $\mathrm{P}<0.05$ & $\mathrm{~ns}$ \\
\hline
\end{tabular}

$\mathrm{P}<0.05$, different letters indicate means significantly different, ns: not significant

\section{Water-Retention Capacity of the Leaf}

For all varieties, the differences between the applications were found to be statistically significant. The water-retention capacity of the leaf, which decreased via the drought application in comparison to the control for all varieties, exhibited a significant increase due to the salicylic acid application (Table 4). Gokmen (2011) and Gunes et al. (2006) established that water-retention capacity of the leaf decreased significantly as a result of the drought stress, Coban (2007) and Guneri Bagci (2010) found that water-retention capacity of the leaf increased in some of the varieties/genotypes and decreased in some others under drought conditions. It is considered that different results in different research were obtained depending on plant species, cultivating conditions and the severity of the drought. Increased waterretention capacity of the leaf as a result of the salicylic acid applications could be explained via the acquired strength of the plant towards stress conditions or via the osmolytes that accumulate in the leaves decreasing the osmotic potential, thus the increase in the amount of water retrieved from the soil.

Table 4. The Effect of Salicylic Acid on the Water-Retention Capacity of the Leaf of the Wheat Varieties Cultivated under Drought Conditions

\begin{tabular}{llllll}
\hline Water-Retention Capacity of the Leaf $(\mathrm{g} g-1$ hour-1)(mean \pm standard deviation $(\mathrm{n}=4)$ \\
\hline \multirow{2}{*}{ Applications } & \multicolumn{5}{c}{ Varieties } \\
\cline { 2 - 6 } & Tir & Doğu-88 & Alparslan & Altay 2000 & Bezostaja1 \\
\hline Control & $0.22 \pm 0.07^{\mathrm{ab}}$ & $0.22 \pm 0.04^{\mathrm{ab}}$ & $0.30 \pm 0.11^{\mathrm{ab}}$ & $0.14 \pm 0.00^{\mathrm{ab}}$ & $0.17 \pm 0.07^{\mathrm{ab}}$ \\
Drought & $0.14 \pm 0.02^{\mathrm{b}}$ & $0.16 \pm 0.03^{\mathrm{b}}$ & $0.07 \pm 0.01^{\mathrm{b}}$ & $0.08 \pm 0.00^{\mathrm{b}}$ & $0.09 \pm 0.01^{\mathrm{b}}$ \\
Drought+SA1 & $0.30 \pm 0.27^{\mathrm{ab}}$ & $0.14 \pm 0.04^{\mathrm{b}}$ & $0.07 \pm 0.00^{\mathrm{b}}$ & $0.11 \pm 0.00^{\mathrm{ab}}$ & $0.15 \pm 0.02^{\mathrm{ab}}$ \\
Drought+SA2 & $0.55 \pm 0.04^{\mathrm{a}}$ & $0.57 \pm 0.10^{\mathrm{a}}$ & $0.60 \pm 0.03^{\mathrm{a}}$ & $0.48 \pm 0.95^{\mathrm{a}}$ & $0.59 \pm 0.01^{\mathrm{a}}$ \\
$\mathrm{P}$ value & $\mathrm{P}<0.05$ & $\mathrm{P}<0.01$ & $\mathrm{P}<0.01$ & $\mathrm{P}<0.01$ & $\mathrm{P}<0.01$ \\
\hline
\end{tabular}

$\mathrm{p}<0.01, \mathrm{P}<0.05$ different letters indicate means significantly different 


\section{Fresh and Dry Weight Above Ground}

The differences between the applications in terms of the fresh weight above ground and dry weight above ground was found statistically significant for all varieties. Fresh weight above ground that decreases with drought and the dry weight above ground increased in accordance with the application dosage of the salicylic acid for Tir, Doğu-88 and Altay 2000 varieties, decreased in Bezostajal variety due to $\mathrm{SA}_{1}$ dosage and increased due to $\mathrm{SA}_{2}$ dosage, and with Alparslan variety fresh weight above ground and dry weight above ground decreased as the application dosage increased (Table 5 and Table 6). The studies of Cuevas et al. (2006) and Praxedes et al. (2006) described that the reduction in plant weight under drought conditions could stem from the decrease in stoma conductivity associated with water deficiency, from the inhibition of $\mathrm{CO}_{2}$ uptake and loss of photosynthetic pigment, or from the decrease in the rate of photosynthesis activity due to the damage occurred in the membranes. The increase in the rate of photosynthesis via salicylic acid application causes a change in the plant's biosynthesis of the protein, thus this phenomenon could be explained to regulate the growth and development of the plant, thereby increasing its fresh weight. Singh and Usha
(2003) and Turkyilmaz et al. (2005) stated that salicylic acid increased fresh weight of the plant under stress conditions, respectively, for wheat and beans. Several researchers, on the other hand, reported that salicylic acid reduced the transpiration rate and thus reduced the plant's water intake capacity, and therefore exhibited an inhibiting effect on the plant growth LarqueSaavedra (1978) and salicylic acid caused a decrease in fresh weight (Coban, 2007).In studies conducted on different plants under drought conditions, Ayas and Demirtas (2009) and Kusvuran et al. (2011) stated that drought stress caused a decrease in the dry weight of the plants. On the contrary, Turkyilmaz et al.(2005) and Khan et al. (2003) reported that salicylic acid increased the dry weight of the plant under stress conditions. Singh and Usha (2003) and Barkosky and Einhellig (1993) reported that salicylic acid enhanced leaf strength under stress conditions, while preserving the water potential of the plant by reducing transpiration. Moreover, as the varieties exhibited different reactions to salicylic acid applications, in the studies of Turkyilmaz et al. (2005) and Canakci (2010) it was stated that the response of a same variety could be different as the concentrations would change.

Table 5. The Effect of Salicylic Acid on the Above Ground Fresh Weight of the Wheat Varieties Cultivated under Drought Conditions

\begin{tabular}{lllllc}
\hline \multicolumn{5}{l}{ Above Ground Fresh Weight $(\mathrm{g} \mathrm{b}-1)($ mean \pm standard deviation $(\mathrm{n}=4)$} \\
\hline \multirow{2}{*}{ Applications } & \multicolumn{5}{c}{ Varieties } \\
\cline { 2 - 6 } & Tir & Doğu 88 & Alparslan & Altay 2000 & Bezostaja1 \\
\hline Control & $3.62 \pm 0.36^{\mathrm{a}}$ & $3.76 \pm 0.84^{\mathrm{a}}$ & $3.73 \pm 0.37^{\mathrm{a}}$ & $5.35 \pm 0.62^{\mathrm{a}}$ & $3.73 \pm 1.19^{\mathrm{a}}$ \\
Drought & $0.85 \pm 0.05^{\mathrm{b}}$ & $1.40 \pm 0.26^{\mathrm{b}}$ & $2.54 \pm 0.29^{\mathrm{ab}}$ & $0.91 \pm 0.01^{\mathrm{b}}$ & $1.52 \pm 0.36^{\mathrm{ab}}$ \\
Drought+SA1 & $1.62 \pm 0.47^{\mathrm{ab}}$ & $1.59 \pm 0.29^{\mathrm{ab}}$ & $2.14 \pm 0.62^{\mathrm{ab}}$ & $1.58 \pm 0.31^{\mathrm{ab}}$ & $1.29 \pm 0.02^{\mathrm{b}}$ \\
Drought+SA2 & $2.86 \pm 1.81^{\mathrm{ab}}$ & $2.93 \pm 1.18^{\mathrm{ab}}$ & $1.85 \pm 0.56^{\mathrm{b}}$ & $2.22 \pm 0.52^{\mathrm{ab}}$ & $3.55 \pm 0.89^{\mathrm{b}}$ \\
$\mathrm{P}$ value & $\mathrm{P}<0.01$ & $\mathrm{P}<0.01$ & $\mathrm{P}<0.05$ & $\mathrm{P}<0.01$ & $\mathrm{P}<0.01$ \\
\hline $\mathrm{P}<0.01$ & $\mathrm{P}<0.05$ & &
\end{tabular}

$\mathrm{P}<0.01, \mathrm{P}<0.05$ different letters indicate means significantly different 
Table 6. The Effect of Salicylic Acid on the Above Ground Dry Weight of the Wheat Varieties Cultivated under Drought Conditions

\begin{tabular}{llllll}
\hline \multicolumn{5}{c}{ Above Ground Dry Weight $(\mathrm{g} \mathrm{b}-1)$} & $(\mathrm{mean} \pm$ standard deviation $(\mathrm{n}=4)$ \\
\hline \multirow{2}{*}{ Applications } & \multicolumn{5}{c}{ Varieties } \\
\cline { 2 - 6 } & Tir & Doğu-88 & Alparslan & Altay 2000 & Bezostaja1 \\
\hline Control & $0.78 \pm 0.08^{\mathrm{a}}$ & $0.85 \pm 0.14^{\mathrm{a}}$ & $0.87 \pm 0.05^{\mathrm{a}}$ & $1.24 \pm 0.17^{\mathrm{a}}$ & $0.84 \pm 0.20^{\mathrm{ab}}$ \\
Drought & $0.30 \pm 0.06^{\mathrm{b}}$ & $0.40 \pm 0.05^{\mathrm{b}}$ & $0.87 \pm 0.04^{\mathrm{ab}}$ & $0.29 \pm 0.05^{\mathrm{b}}$ & $0.48 \pm 0.07^{\mathrm{ab}}$ \\
Drought+SA1 & $0.47 \pm 0.16^{\mathrm{ab}}$ & $0.45 \pm 0.05^{\mathrm{ab}}$ & $0.54 \pm 0.14^{\mathrm{ab}}$ & $0.46 \pm 0.38^{\mathrm{ab}}$ & $0.43 \pm 0.04^{\mathrm{b}}$ \\
Drought+SA2 & $0.76 \pm 0.49^{\mathrm{ab}}$ & $0.72 \pm 0.30^{\mathrm{ab}}$ & $0.50 \pm 0.09^{\mathrm{b}}$ & $0.57 \pm 0.06^{\mathrm{ab}}$ & $0.93 \pm 0.26^{\mathrm{a}}$ \\
$\mathrm{P}$ value & $\mathrm{P}<0.05$ & $\mathrm{P}<0.05$ & $\mathrm{P}<0.01$ & $\mathrm{P}<0.01$ & $\mathrm{P}<0.01$ \\
\hline $\mathrm{P}<0.01, \mathrm{P}<0.05$ different letters indicate means significantly different & &
\end{tabular}

$\mathrm{P}<0.01, \mathrm{P}<0.05$ different letters indicate means significantly different

\section{Fresh and Dry Weight Underground}

The differences between the applications in terms of underground fresh weight were found statistically significant for Tir, Altay 2000 and Bezostajal varieties, in terms of underground dry weight the differences were found statistically significant in all varieties except for the Doğu-88. The underground fresh weight, which decreased due to drought, increased in Tir and Altay 2000 varieties as a result of the salicylic acid applications, while in Bezostaja 1 variety underground fresh weight decreased via $\mathrm{SA}_{1}$ application and reached the highest value via $\mathrm{SA}_{2}$ application. For the Alparslan variety, the underground dry weight increased due to drought and decreased as a result of the salicylic acid applications. For Tir, Altay 2000 and Bezostaja1 varieties, the underground dry weight, which decreases under drought conditions, increased in Tir with salicylic acid application, decreased in Altay 2000 variety, and decreased due to $\mathrm{SA}_{1}$ application and reached to a maximum underground dry weight value with $\mathrm{SA}_{2}$ application in Bezostaja1 variety (Table 7 and Table 8).

Turkyilmaz et al. (2005) stated that salicylic acid applied to beans in greenhouse and field conditions did not have a significant effect under greenhouse conditions on the root fresh weight, yet increased root fresh weight under field conditions. In addition, Canakci, (2010) reported that two low doses $(0.1 \mathrm{mM}, 10 \mathrm{mM})$ of salicylic acid increased the fresh root weight of the barley plant, whereas the two higher doses $(100 \mathrm{mM}$, $200 \mathrm{mM}$ ) decreased the fresh root weight via toxic effect. Several researchers stated that high concentrations of salicylic acid decrease the value of fresh weight through presenting a growth and development inhibiting effect on the plant (Canakci and Munzuroglu 2006; Abdalla and El-Khoshiban, 2007). Plants cultivate optimally in proportion to the suitability of the water and environmental conditions they require. The lack of appropriate conditions or stress conditions adversely affect the plants. Indeed, Ohashi et al. (2009) and Kusvuran (2010) stated that the underground dry weight for a plant under drought stress decreases. Yet, Jung et al. (1999) and Turkyilmaz et al. (2005) reported that salicylic acid application contributes to plant strength and growth under stress conditions, and one of these contributions is the increase in the dry weight.

Table 7. The Effect of Salicylic Acid on the Underground Dry Weight of the Wheat Varieties Cultivated under Drought Conditions

\begin{tabular}{llllll}
\hline \multicolumn{5}{c}{ Underground Dry Weight $(\mathrm{g} \mathrm{b}-1)($ mean \pm standard deviation $(\mathrm{n}=4)$} \\
\hline \multirow{2}{*}{ Application } & \multicolumn{5}{c}{ Varieties } \\
\cline { 2 - 6 } & Tir & Doğu-88 & Alparslan & Altay 2000 & Bezostaja 1 \\
\hline Control & $1.72 \pm 0.17^{\mathrm{a}}$ & $1.59 \pm 0.83$ & $1.66 \pm 0.38$ & $2.72 \pm 0.32^{\mathrm{a}}$ & $2.12 \pm 0.53^{\mathrm{ab}}$ \\
Drought & $0.92 \pm 0.14^{\mathrm{b}}$ & $1.06 \pm 0.08$ & $1.52 \pm 0.21$ & $0.90 \pm 0.07^{\mathrm{b}}$ & $1.17 \pm 0.10^{\mathrm{ab}}$ \\
Drought $+\mathrm{SA}_{1}$ & $1.49 \pm 0.25^{\mathrm{ab}}$ & $1.27 \pm 0.26$ & $1.06 \pm 0.36$ & $1.44 \pm 0.32^{\mathrm{ab}}$ & $1.05 \pm 0.19^{\mathrm{b}}$ \\
Drought $+\mathrm{SA}_{2}$ & $1.23 \pm 0.31^{\mathrm{ab}}$ & $1.99 \pm 0.48$ & $1.13 \pm 0.07$ & $1.28 \pm 0.20^{\mathrm{ab}}$ & $2.40 \pm 0.38^{\mathrm{a}}$ \\
$\mathrm{P}$ value & $\mathrm{P}<0.05$ & ns & ns & $\mathrm{P}<0.01$ & $\mathrm{P}<0.01$ \\
\hline $\mathrm{P}<0.01, \mathrm{P}<0.05$ different letters indicte &
\end{tabular}

$\mathrm{P}<0.01, \mathrm{P}<0.05$ different letters indicate means significantly different, ns: not significant 
Table 8. The Effect of Salicylic Acid on the Underground Fresh Weight of the Wheat Varieties Cultivated under Drought Conditions

\begin{tabular}{|c|c|c|c|c|c|}
\hline \multicolumn{6}{|c|}{ Underground Fresh Weight $(\mathrm{g} b-1)($ mean \pm standard deviation $(\mathrm{n}=4)$} \\
\hline \multirow{2}{*}{ Applications } & \multicolumn{5}{|c|}{ Varieties } \\
\hline & Tir & Doğu-88 & Alparslan & Altay 2000 & Bezostaja1 \\
\hline Control & $0.46 \pm 0.07^{\mathrm{ab}}$ & $0.40 \pm 0.19$ & $0.42 \pm 0.04^{\mathrm{ab}}$ & $0.84 \pm 0.17^{\mathrm{a}}$ & $0.68 \pm 0.33^{\mathrm{ab}}$ \\
\hline Drought & $0.29 \pm 0.04^{\mathrm{b}}$ & $0.33 \pm 0.04$ & $0.58 \pm 0.07^{\mathrm{a}}$ & $0.46 \pm 0.41^{\mathrm{ab}}$ & $0.38 \pm 0.06^{\mathrm{ab}}$ \\
\hline Drought+SA1 & $0.47 \pm 0.08^{\mathrm{a}}$ & $0.41 \pm 0.05$ & $0.43 \pm 0.12^{\mathrm{ab}}$ & $0.27 \pm 0.12^{\mathrm{b}}$ & $0.37 \pm 0.04^{\mathrm{b}}$ \\
\hline Drought + SA2 & $0.37 \pm 0.07^{\mathrm{ab}}$ & $0.55 \pm 0.14$ & $0.31 \pm 0.02^{\mathrm{b}}$ & $0.44 \pm 0.05^{\mathrm{ab}}$ & $0.79 \pm 0.23^{\mathrm{a}}$ \\
\hline $\mathrm{P}$ value & $\mathrm{P}<0.05$ & ns & $\mathrm{P}<0.05$ & $\mathrm{P}<0.01$ & $\mathrm{P}<0.05$ \\
\hline
\end{tabular}

$\mathrm{P}<0.01, \mathrm{P}<0.05$ different letters indicate means significantly different, ns: not significant

\section{CONCLUSION}

Due to the fact that wheat, which is mostly grown in dry farming system in Turkey, is affected during the whole vegetation period, grain productivity per unit area becomes subject to fluctuations. It is essential to identify and disseminate applications that reduce the adverse effects of drought, which leads to conditions that abiotic stress factors are negatively reflected in production. In this respect, this study, which focuses on the effect of salicylic acid on growth and several physiological characteristics of wheat varieties under drought conditions, determined that the responses of the varieties to the drought are different. The salicylic acid application, in terms of the investigated characteristics, was found to be adversely affecting the Alparslan variety in general, effective in increasing the tolerance to drought in the Tir wheat population line and the Doğu-88, Altay 2000, Bezostaja1 varieties and exhibited differences with respect to the dosages of salicylic acid $\left(0.1 \mathrm{mM} \mathrm{kg}^{-1} \mathrm{SA}\right.$ ve $1.0 \mathrm{mM} \mathrm{kg}^{-1}$ SA). These results indicate that salicylic acid could be utilized as an effective growth regulator for plants in obtaining tolerance to drought. This study would provide an insight for further studies, since the type, application method, type and dosage of salicylic acid utilized might vary.

\section{ACKNOWLEDGEMENTS}

This research was founded YYU 2014-FBED136 Number of Projects by The YYU Scientific Researh Presidency .

\section{REFERENCES}

Abdalla MM, El-Khoshiban NH, 2007. The Influence of Water Stress on Growth, Relative Water Content, Photosynthetic Pigments, Some Metabolic and Hormonal Contents of Two Triticium aestivum Cultivars. Journal of Applied Sciences Research, 3 (12): 2062-2074.

Anonymous, 2016a. Food Outlook, http://www.fao.org/docrep/016/al993e/al993e00. pdf. 05.11.2016

Anonymous, 2016b. Statistics of Agriculture. Statistics of Plant Production, http://www.tuik.gov.tr/UstMenu.do?metod=teme list. 05.11.2016.

Ayas S, Demirtas C, 2009. Deficit Irrigation Effects on Cucumber (Cucumis sativus L. Maraton) Yield in Unheated Greenhouse Condition. Journal of Food, Agriculture \& Environment,7 (3,4) : 645 649.

Bajji M, Kinet JM, Lutts S, 2002. The Use of the Electrolyte Leakage Method for Assessing Cell Membrane Stability as A Water Stress Tolerance Test in Durum Wheat. Plant Growth Regulation, 36 (1): 61-70.

Barkosky RR, Einhellig FA, 1993. Effects of Salicylic Acid on Plant Water Relationship, Journal of Chemical Ecology, 19, 237-247.

Beeflink WG, Rozema J, Huiskes AEL, 1985. Ecology of Coastal Vegetation. 2nd Edn., W. Junk Publication. USA. ISBN: 9061935318, pp: 640.

Blum A, Ebrecon A, 1981. Cell membrane stability as measure of drought and heat tolerance in wheat. Crop Science; 21:43-7.

Bray JR, 1963. Root production and the estimation of net productivity. Canadian Journal of Botany, 41(1), 65-72. 
Canakci S, Munzuroglu O, 2006. Effects of Acetylsalicylic Acid on Growth and Transpiration Rate of Corn (Zea mays L.) Seedlings. Science and Engineering Journal of Firat University. (4), $479-484$.

Canakci S, 2010. The effects of Salicylic Acid and ferulic acid on germination, various grovth parameters and amount of pigments on barley (Hordeum vulgare L.) seeds.Firat University Journal of Science ., 22 (1), 37-45.

Coban SS, 2007. Effect Of Salicylic Acid On Physiological Parameters Symptomatic For Drought Stress And Mineral Nutrition Of Chickpea Genotypes. Master Thesis. Ankara University Graduate School of Natural and Applied Sciences, Department of Soil Science.

Cuevas E, Baeza P, Lissarrague JR, 2006. Variation in stomatal behaviour and gas exchange between mid-morning and mid-afternoon of north-south oriented grapevines (Vitis vinifera L. cv. tempranillo) at different levels of soil water availability, Science Horticultural, 108, 173-180.

El-Tayeb MA, 2005. Response of Barley Grains to The Interactive Effect of Salinity and Salicylic Acid. Plant Growth Regulation,45: 215-224.

Ferreira ME, Satagopan J, Yandell B, Williams PH, Osborn TC, 1995. Mapping loci controlling vernalization requirement and flowering time in Brassica napus. Theoretical and Applied Genetics,90: 727- 732.

Gokmen E, 2011. Some Physiological And Biochemical Showed Chickpea Genotypes Against Drought Stress Determination Reactions.MS Thesis. The Graduate School of Natural and Applied Science of Selcuk University the Degree of Master of Science in Field Crops. Konya.

Guneri Bagci E, 2010. Determination of Physiological and Biochemical Parameters Symptomatic for Oxidative Stress in Chickpea (Cicer arietinum L.) Cultivars Under Drought.Ph.D. Thesis. Ankara University, Graduate School of Natural ve Applied Sciences, Department of Soil Science. Ankara
Gunes A, Adak MS, Inal A, Alpaslan M, Eraslan F, Cicek N, Kayan N, Soylu B, 2006. Oxidatie Stress Depending on Drought and Determination Physiological Tolerance Mechanism in Chickpea and Lentil cultivars. Scientific Research Project. Ankara University.

Jagtap V, Bhargava S, Streb P, Feierabend J, 1998. Comparative effect of water, heat and light stress on photosynthetic reaction in Sorghum biocolor (L.) Moench. Journal Experimental Botany. 49: 1715-1721.

Jones MM, Turner NC, 1978. Osmotic adjustment in leaves of Sorghumin response to water deficits. Plant Physiology, 61, 122-126.

Jung B, Alsanius, BW, Jensen P, 1999. Effects of some plant and microbial metabolites on germination and emergence of tomato seedlings. In International Symposium on Growing Media and Hydroponics. 548(pp. 603-610).

Kabiri R, Nasibi F, Farahbakhsh H, 2014. Effect of exogenous salicylic acid on some physiological parameters and alleviation of drought stress in Nigella sativa plant under hydroponic culture. Plant Protect. Science,50: 43-51.

Kacar B, 1995. Chemical Analysis of Plant and Soil III. A.U.A.F. Publications of Education, Research and Development Foundation. (3), pp: 255.

Kaydan D, Yagmur M, Okut N, 2007. Effects of Salicylic Acid on the Growth and Some Physiological Characters in Salt Stressed Wheat (Triticum aestivum L.). Ankara University, Faculty of Agriculture, Journal of Agricultural Sciences, 13 (2): 114-119.

Kaydan D, Yagmur M, 2008. A Research on Yield and Yield Components of Some Bread Wheat (Triticum aestivum L.) Varieties in Van Ecological Conditions, Ankara University, Faculty of Agricultural Sciences, 14 (4), 350358.

Khaliq I, Shah SAH, Ahsan M, 1999. Evaluation of Spring Wheat ( Triticum aestivum L.) For Drought Field Conditions. Pakistan Journal of Biological Sciences, 2 (3): 1006-1009. 
Khan W, Prithiviraj B, Smith DL, 2003. Photosynthetic responses of corn and soybean to foliar application of salicylates. Journal of Plant Physiology. 160, 485-492.

Kulshreshta S, Mishra DP, Gupta RK, 1987. Changes in content of cholorophyll, proteins and lipids in whole choloplast and chloroplast membrane fractions at different leaf water potentials in drought resistant and sensitive genotypes of wheat. Photosynthetica, 21(1): 65-70.

Kusvuran S, 2010. Relationships Between Physiological Mechanisms of Tolerances to Drought And Salinity in Melons. Ph. D. Thesis. Department of Horticulture Institute of Natural and Applied Sciences University of Cukurova. Adana.

Kusvuran S, Dasgan HY, Abak K, 2011. Responses of different melon genotypes to drought stress. Yuzuncu Yil University Journal of Agricultural Sciences, 21(3): 209-219.

Larque-Saavedra A, 1978. The antitranspirant effect of acetylsalicylic acid on Phaseolus vulgaris. Physiology Plant.,43: 126-128.

Mensah JK, Obadoni BO, Eroutor PG, Onome-Irieguna F, 2006. Simulated flooding and drought effects on germination, growth and yield parameters of Sesame (Seasamum indicum L.). African Journal of Biotechnology., 5: 1249-1253.

Monti LM, 1986. Breeding Plants for Drought Resistance: The Problem and its Relevance. Drought Resistance in Plants. Meeting Held in Amalfi, 19 to 23 October 1986, Belgium, 1-8.

Munns R, Shazia H, Rivelli AR, James RA, Condon AG, Lindsay MP, 2002. Avenues for increasing salt tolerance of crops and the role of physiologically based selection traits. Plant Soil. 247: 93-105.

Mutlu S, Karadagoglu O, Atici O, Tasgin E, Nalbantoglu B, 2013. Time-dependent effect of salicylic acid on alleviating cold damage in two barley cultivars differing in cold tolerance. Turkish Journal of Botany, 37: 343-349.

Nemeth M, Janda T, Hovarth E, Paldi E, Szali G, 2002. Exogenous salicylic acid increases polyamine content but may decrease drought tolerance in maize. Plant Science,162: 569-574.
Ohashi Y, Nakayama N, Saneoka H, Mohapatra KP, Fujita K, 2009. Differences in the Responses of Stem Diameter and Pod Thickness To Drought Stress During the Grain Filling Stage in Soybean Plants. Acta Physiol Plant, 31: 271-277.

Perez-Lopez U, Robredo A, Lacuesta M, Mena-Petite A, Munoz-Rueda A, 2008. The Impact of Salt Stress on the Water Status of Barley Plants is Partially Mitigated by Elevated $\mathrm{CO} 2$. Environmental and Experimental Botany,66 (3): 463-470.

Praxedes SC, DaMatta FM, Loureiro ME, Ferrao MAG, Cordeiro AT, 2006. Effects of long-term soil drought on photosynthesis and carbohydrate metabolism in mature robusta coffee (Coffea canephora Pierre var. kouillou) leaves, Environmental and Experimental Botany,56, 263-273.

Premchandra GS, Saneoka H, Ogata S, 1990. Cell membrane stability, an indicator of drought tolerance as affected by applied nitrogen in soybean. Journal Agricultural Science Cambridge. 115, 63-66.

Sairam RK, 1994. Effect of moisture-stress on physiological activities of two contrasting wheat genotypes. Indian Journal of Experimental Biology, 32, 594-594.

Singh B, Usha K, 2003. Salicylic acid induced physiological and biochemical changes in wheat seedlings under water stress. Plant Growth Regulation. 39, 137-141.

Tavakkolli E, Fatehi F, Rengasamy P, McDonald G, 2012. A comparison of hydroponic and soilbased screening methods to identify salt tolerance in the field in barley. Journal of Experimental Botany, 63(10): 3853-3868.

Turkyilmaz B, Aktas LY, Guven A, 2005. Salicylic acid induced some biochemical and physiological changes in Phaseolus vulgaris L.Science and Engineering Journal of Firat University.17 (2), 319-326. 